\title{
Mount St. Helens, 1980 to Now-What's Going On?
}

ount St. Helens seized
the world's attention in
1980 when the largest historical
landslide on Earth and a powerful
explosive eruption reshaped the
volcano, created its distinctive cra-
ter, and dramatically modified the
surrounding landscape. An enor-
mous lava dome grew episodically
in the crater until 1986, when the
volcano became relatively quiet.
A new glacier grew in the crater,
wrapping around and partly burying
the lava dome. From 1987 to 2003,
sporadic earthquake swarms and
small steam explosions indicated
that magma (molten rock) was be-
ing replenished deep underground.
In 2004, steam-and-ash explosions
heralded the start of another erup-
tion. A quieter phase of continuous
lava extrusion followed and lasted
until 2008, building a new dome
and doubling the volume of lava
on the crater floor. Scientists with
the U.S. Geological Survey and
University of Washington's Pacific
Northwest Seismograph Network
maintain constant watch for signs
of renewed activity at Mount St.
Helens and other Cascade volca-
noes. Now is an ideal time for both
actual and virtual visitors to Mount
St. Helens to learn more about dra-
matic changes taking place on and
beneath this active volcano.

Civilization exists by geological consent, subject to change without notice.

\section{-Will Durant}

The spectacular 1980 eruption at Mount St. Helens opened a new episode in the volcano's history that began more than 250,000 years ago. Fifty-seven people lost their lives as a result of the eruption, and dramatic changes to the landscape occurred and will continue long into the future. Lava domes grew U.S. Department of the Interior U.S. Geological Survey

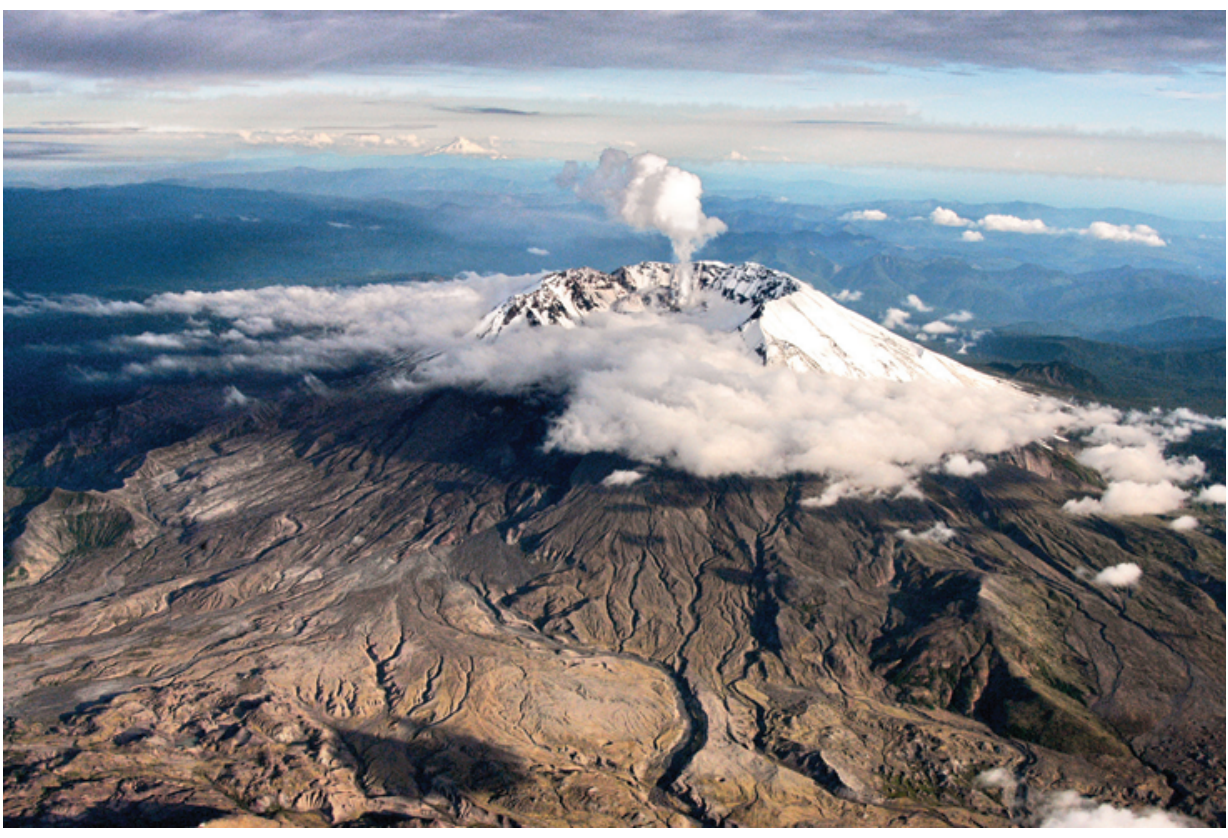

More is going on than meets the eye in this south-facing photo of Mount St. Helens taken on June 8, 2005. An unrelenting flow of semi-solid magma rises from a vent on the crater floor at a rate of about 10 feet per day, pushing up skyscraper-size spines. The spines collapse to form a steaming mound of lava called a lava dome. Split in two by the growing dome, Crater Glacier has started to flow more quickly northward. When the eruption ended in early 2008, the two arms of the glacier had met again after encircling both the new dome and an earlier one that grew from 1980 to 1986. Stream channels near the bottom of the photo continued to erode, and massive amounts of sediment moved downstream, clogging rivers and increasing the threat of floods - processes that will continue far into the future. In the distance are two other Cascade Range volcanoes-Oregon's Mount Hood (left) and Mount Jefferson (center). USGS photo by John Pallister.

in the 1980 crater during $1980-86$ and 2004-8. A new glacier - Crater Glacier -formed, and streams began eroding and transporting millions of tons of sediment downstream. Years later, hot dome rocks are still steaming, Crater Glacier is still advancing, rock falls send plumes of dust skyward, and streams continue to erode and transport sediment away from the volcano. Meanwhile, magma (molten rock) is accumulating again beneath the volcano. Scientists are keeping a close watch on Mount St. Helens and the other Cascade volcanoes to assess hazards and provide timely warnings of future activity. Arming yourself with knowledge and following a few simple recommendations will help you prepare for future eruptions.

Throughout these pages, the camera symbol ( $\left[\begin{array}{l}\square \\ \square\end{array}\right)$ calls attention to video clips of volcanic processes that can be accessed from the online version of this Fact Sheet (http://pubs.usgs.gov/ fs/2013/3014). For more information about volcanoes in the United States and around the world, visit the U.S. Geological Survey (USGS) Volcano Hazards Program website: http://volcanoes.usgs. gov/.

\section{0 -Earth's Inner Fury Uncorked}

On May 18, 1980, Mount St. Helens in southwest Washington State erupted violently, killing 57 people. The picturesque conical volcano had been rumbling for months, but on that morning its north side collapsed in one of the largest debris avalanches (landslides) in history, triggering a lateral blast that devastated 150 square miles and sent up an eruption column that reached 
the stratosphere and blanketed areas hundreds of miles downwind with ash. The eruption also initiated lahars (volcanic mudflows) that choked nearby rivers. The landslide deposit - its surface strewn with huge blocks of shattered rock called hummocks - buried the North Fork of the Toutle River valley as much as 600 feet (180 meters) deep for a distance of 13 miles (21 kilometers). Part of the landslide overtopped a ridge 1,150 feet (350 meters) high 6 miles (10 kilometers) north of the volcano, leaving a deposit called The Run-Up or The Spillover. The eruption destroyed nearly all of the volcano's glaciers, and lahars choked the Toutle, Cowlitz, and Columbia River channels with sediment. Pyroclastic flows - ground-hugging avalanches of hot volcanic ash, pumice, rock fragments, and gases that destroy everything in their path - rushed out of the crater left by the landslide and formed the Pumice Plain in the valley below. Five more explosive eruptions during summer 1980 sent columns of ash jetting into the stratosphere, disrupting life in the Pacific Northwest and threatening air travel.

From December 1980 to October 1986, a lava dome grew episodically on the crater floor, eventually reaching a height of nearly 1,000 feet (305 meters) and a volume of 120 million cubic yards (92 million cubic meters). Snowfall and avalanches from the steep crater walls collected on the crater floor, where they were shaded from sunlight during most of the year. As a result, Crater Glacier formed and began to flow-the newest and only expanding glacier in the Cascade Range. Newly formed streams began the monumental task of eroding and transporting millions of tons of sediment downstream. More than three decades later, only about 8 percent of the sediment dumped into the river system in 1980 has been eroded away. The downstream flood threat from rivers clogged with mobilized sediment will require attention for decades to come.

\section{4-The Volcano Erupts Again}

In September 2004, almost 18 years after the 1980-86 lava dome stopped growing, a swarm of shallow earthquakes and a rapidly growing welt on the crater floor signaled that Mount St. Helens was about to erupt again. Scientists warned that a new eruption could start explosively, and on October 1 the first of several explosions shot a plume of volcanic ash and gases into the sky. Lava emerged from the top of the welt about 10 days later. For the next 3+ years, scientists and spectators alike marveled as a series of hot, solid, smooth-sided lava "spines" rose from the vent, bulldozed their way across the crater floor, and piled up to form a new dome 1,500 feet (455 meters) high.

Crater Glacier was split in two by the growing dome and shoved against the surrounding crater walls. The glacier responded by flowing northward around the east and west sides of the 1980-86 dome at rates

\section{By the Numbers: The 1980 Eruption}

1,314 feet (400 meters) - Elevation lost during May 18, 1980, landslide and eruption-from 9,677 feet (2,950 meters) before to 8,363 feet (2,550 meters) after

2,084 feet (635 meters) - Depth of crater formed in 1980

0.60 cubic miles ( 2.5 cubic kilometers; 3.3 billion cubic yards; 165 million large dump trucks) - Volume of May 18, 1980, landslide deposit

$\mathbf{8 0 , 0 0 0}$ feet (24,000 meters) - Height reached by May 18, 1980 eruption column in less than 15 minutes. The ash cloud spread across the United States in 3 days and circled Earth in 15 days.

0.26 cubic miles (1.0 cubic kilometers) - Volume of volcanic ash (before compaction by rainfall) erupted on May 18, 1980. Noticeable amounts of ash fell in 11 states.

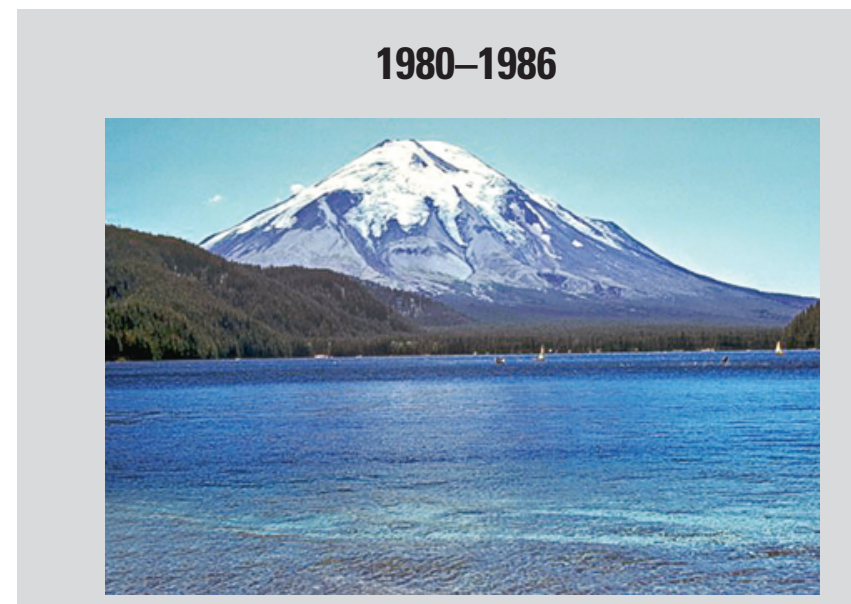

Mount St. Helens as seen from the north shore of Spirit Lake before the May 18, 1980, eruption. USFS photo by Jim Nieland, U.S. Forest Service, Mount St. Helens National Volcanic Monument.

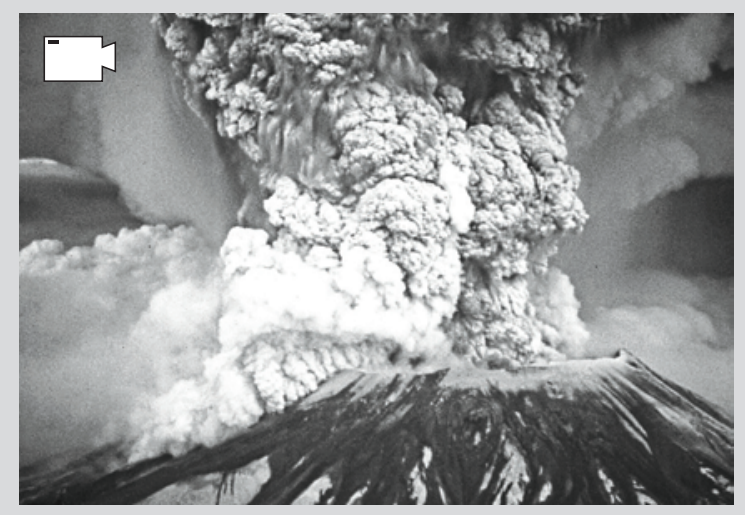

Eruption column at Mount St. Helens on May 18, 1980, as seen from the west. Prevailing winds carried most of the ash to the east. The resulting deposit was more than an inch $(2.5 \mathrm{~cm})$ thick in the town of Ritzville, Washington, 200 miles downwind. Some of the finest ash reached the stratosphere and circumnavigated the globe. A pyroclastic flow can be seen descending the volcano's north flank in the lower left part of the photo. USGS photo by Austin Post.

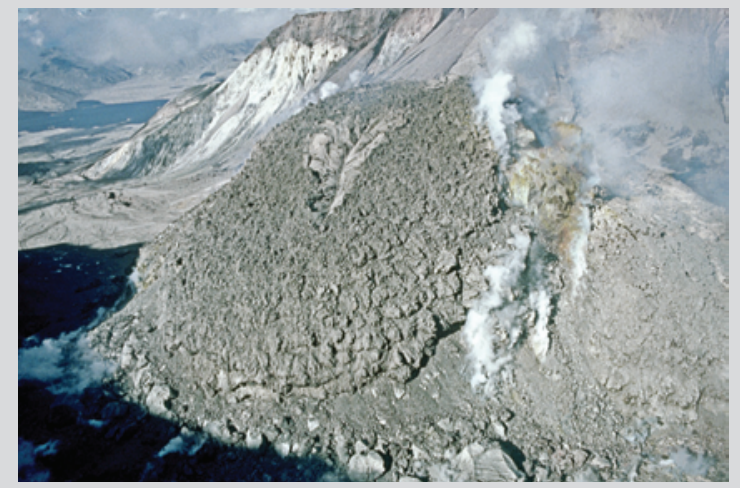

Thick, pasty lava flow emerges onto the surface of the 1980-86 dome on June 26,1981 . The $1980-86$ dome grew episodically by accumulation of more than a dozen flows like this one, plus by internal growth from magma that pushed upward but did not reach the surface. USGS photo by Dan Dzurisin. 


\section{4-PRESENT}

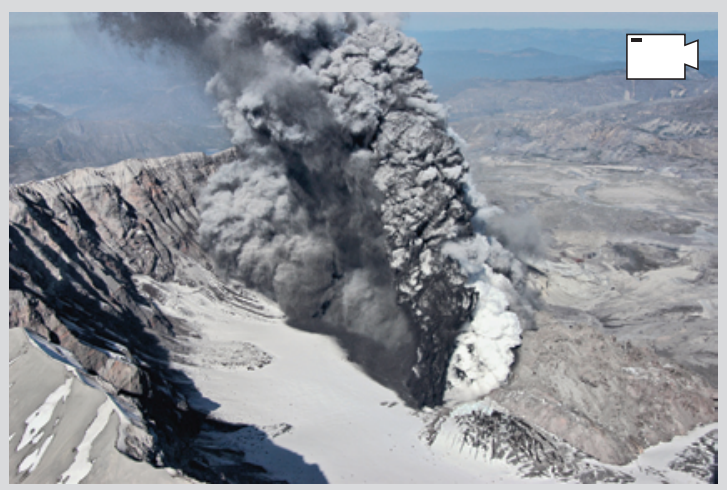

Explosive onset of the 2004-08 dome-building eruption on October 1 , 2004. Light parts of the eruption plume are primarily steam; dark parts are laden with ash and ballistic blocks. The southwest rim of the 1980 crater is on the left. Crater Glacier is between the base of the crater wall and the vent. USGS photo by John Pallister.

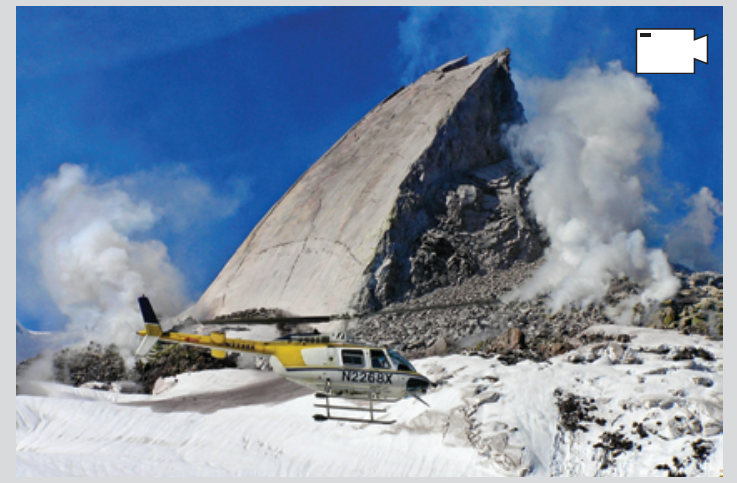

Helicopter flying past lava spine emerging from vent on crater floor. A series of hot, solid lava spines like this one piled up to form the 2004-08 dome. During an eruption, when semisolid magma scrapes against vent walls, it forms a smooth, soft "fault gouge" surface-a texture also seen on rocks lining California's San Andreas fault. USGS photo by Dan Dzurisin, April 28, 2006.

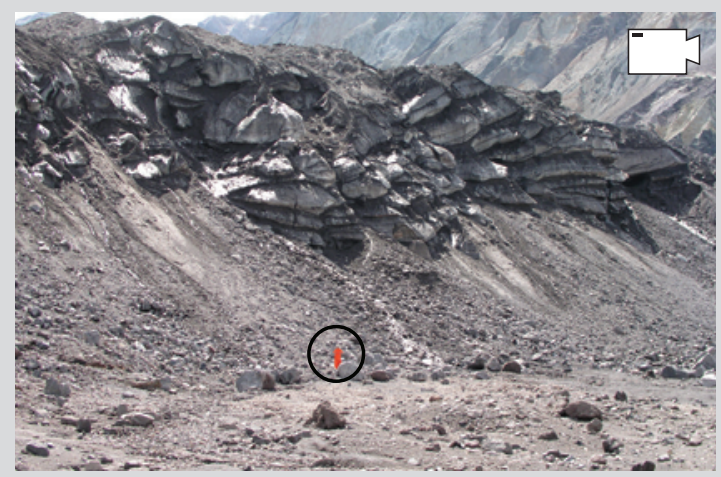

Scientist (circled) examining the toe of Crater Glacier, which advanced northward across the crater floor as a result of the 2004-08 eruption. Rock debris covering the surface of the glacier and incorporated within the glacial ice originated mostly from rockfalls off the steep crater walls or off one of the two lava domes on the crater floor. USGS photo by Dave Ramsey, August 17, 2009. of several feet per day. In early 2008, the two arms of the glacier met on the north side of the dome. By the time the eruption ended in early 2008, the new dome had grown to a volume of 124 million cubic yards (95 million cubic meters) - very nearly the same as the 1980-86 dome. Today (2013), no new lava is being added to the crater and the rate of advance of Crater Glacier has slowed to the pre-2004 value of about 1 foot per day ( 0.3 meters per day).

\section{Dramatic Changes Occur Before Your Eyes and Beneath Your Feet}

Years after the construction of the lava domes of 1980-86 and 2004-8, hot dome rocks are still steaming. Crater Glacier is still advancing and surrounds both domes. Rock falls send plumes of dust skyward. Sediment is the lasting legacy of past eruptions - erosion of 1980 deposits is creating steep-sided channels in the North Fork of the Toutle River valley, and millions of tons of sediment are being carried downstream, increasing flood hazards. This material originated from the upper part of Mount St. Helens, which slid away on May 18, 1980, and it is now on its way to the Columbia River and beyond.

Beneath the volcano, magma is accumulating again and building for another eruption - quite possibly within our lifetimes. Scientists are carefully tracking these and other changes in this most dynamic landscape in the Pacific Northwest.

\section{Silent Forces Beneath Us Create Volcanoes of the Cascade Range}

Slow collisions of Earth's tectonic plates sustain Cascade volcanoes. Mount St. Helens is the most active volcano in the Cascade volcanic arc, a chain of volcanoes stretching 700 miles (1,100 kilometers) from Lassen Peak in northern California to Mount Garibaldi and beyond in southern British Columbia, Canada - part of the famous Pacific "Ring of Fire." The Cascadia section of the Ring of Fire exists because, off the Pacific Northwest coast, the Juan de Fuca Plate is colliding with and sinking beneath the North American Plate at a rate of 1-2 inches ( $3-5$ centimeters) per year. Scientists call this type of boundary between colliding plates a subduction zone, with one plate subducting (sliding beneath) the other. As the plates move, strain builds up in the rocks along subduction zones. This strain is sometimes released in great earthquakes, such as the 1700 Cascadia earthquake off the Pacific Northwest coast and the 2011 Tōhoku earthquake in Japan.

Subduction plays a key role in generating the magmas that form and feed Cascade volcanoes. The surprise ingredient in the

\section{By the Numbers: Mount St. Helens since 1980}

120 million cubic yards (92 million cubic meters; 6.1 million large dump trucks) - Volume of 1980-1986 lava dome

124 million cubic yards (95 million cubic meters; 6.3 million large dump trucks) - Volume of 2004-2008 lava dome

0.88 cubic yards ( 0.67 cubic meters) per second - Average lava extrusion rate October-December 2006 (Equivalent to filling 25 Olympic swimming pools every day)

6 percent-Portion of volume removed on May 18, 1980, that has been replaced by growth of two lava domes

5 feet (1.5 meters) per day-Average advance rate of Crater Glacier during 2004-2008 dome building eruption. Before, its advancement was about 1 foot ( 0.3 meters) per day.

8 percent-Portion of 1980 eruptive material eroded and transported downstream as valley-filling sediment of 2012 
magma-generating process is - water. Deep within the Earth, extreme heat breaks down water-bearing minerals in the sinking Juan de Fuca Plate, releasing hot water into the overlying rocks of the Earth's mantle. The added water lowers the melting temperature of mantle rock, causing some of it to melt. The resulting magma is less dense than surrounding rock, so it rises into the Earth's crust, where its heat triggers more melting and the formation of magma reservoirs. As magma approaches Earth's surface, water vapor and other gases in the magma expand and provide additional energy for a volcanic eruption.

\section{Monitoring Can Provide Advance Warning of Future Eruptions}

Volcanoes generally don't produce large earthquakes like those that occur along plate boundaries, but sometimes swarms of hundreds to thousands of small quakes occur beneath a volcano and provide clues to processes occurring deep underground. Ground deformation (swelling, stretching) occurs when the pressure beneath a volcano changes, which can mean that magma is accumulating or moving toward the surface. A change in the amount or composition of gases released from magma as it rises toward the surface also can foretell an impending eruption. By monitoring and analyzing earthquakes, ground deformation, and volcanic gas emissions, scientists are better able to understand a volcano's behavior, to assess hazards and potential impacts, and to provide timely warnings of future events.
Mount St. Helens is a world-class natural laboratory where USGS and other scientists are learning about processes of rapid landscape change, the magma system that feeds the volcano, and the volcanic and tectonic forces that shape the Pacific Northwest, as well as the warning signs and hazards associated with eruptions. Mount St. Helens is the volcano in the Cascades most likely to erupt again in our lifetimes. The exact timing and magnitude of the next eruption cannot be forecast long in advance, but our growing knowledge base and continued monitoring will enable the USGS to provide short-term forecasts and warnings - as was done in 1980 and 2004.

\section{Those who cannot remember the past are condemned to repeat it.}

\section{-George Santayana}

\section{Be Prepared for Future Eruptions}

Experience has shown that Mount St. Helens tends to be relatively quiet

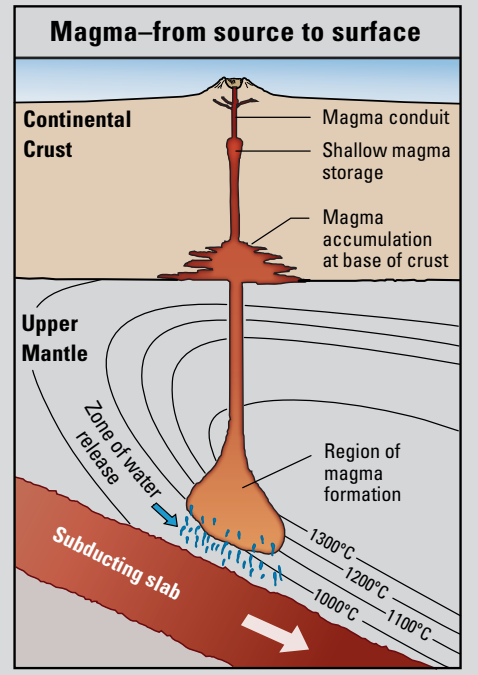

Diagrammatic cross section of a subduction zone, showing locations of magma formation, accumulation, and storage beneath a volcano such as Mount St. Helens. Magma forms above the subducting slab of oceanic crust and accumulates at the base of Earth's rigid crust, then collects in a storage zone 5-8 miles beneath the volcano before eruption. USGS graphic by Lisa Faust.

Block diagram showing subduction of the Juan de Fuca Plate beneath the North American Plate along the Cascadia Trench, which is the western edge of the Cascadia subduction zone. Oceanic crust forms by eruptions along the Juan de Fuca Ridge. As the Juan de Fuca Plate drifts eastward, it cools, becomes more dense, and eventually dives under the less dense North American Plate at the Cascadia Trench. Water released from the subducting slab causes the overlying mantle to partially melt, forming magma that sustains the Cascade Range of volcanoes (black triangles). USGS graphic by Lisa Faust.
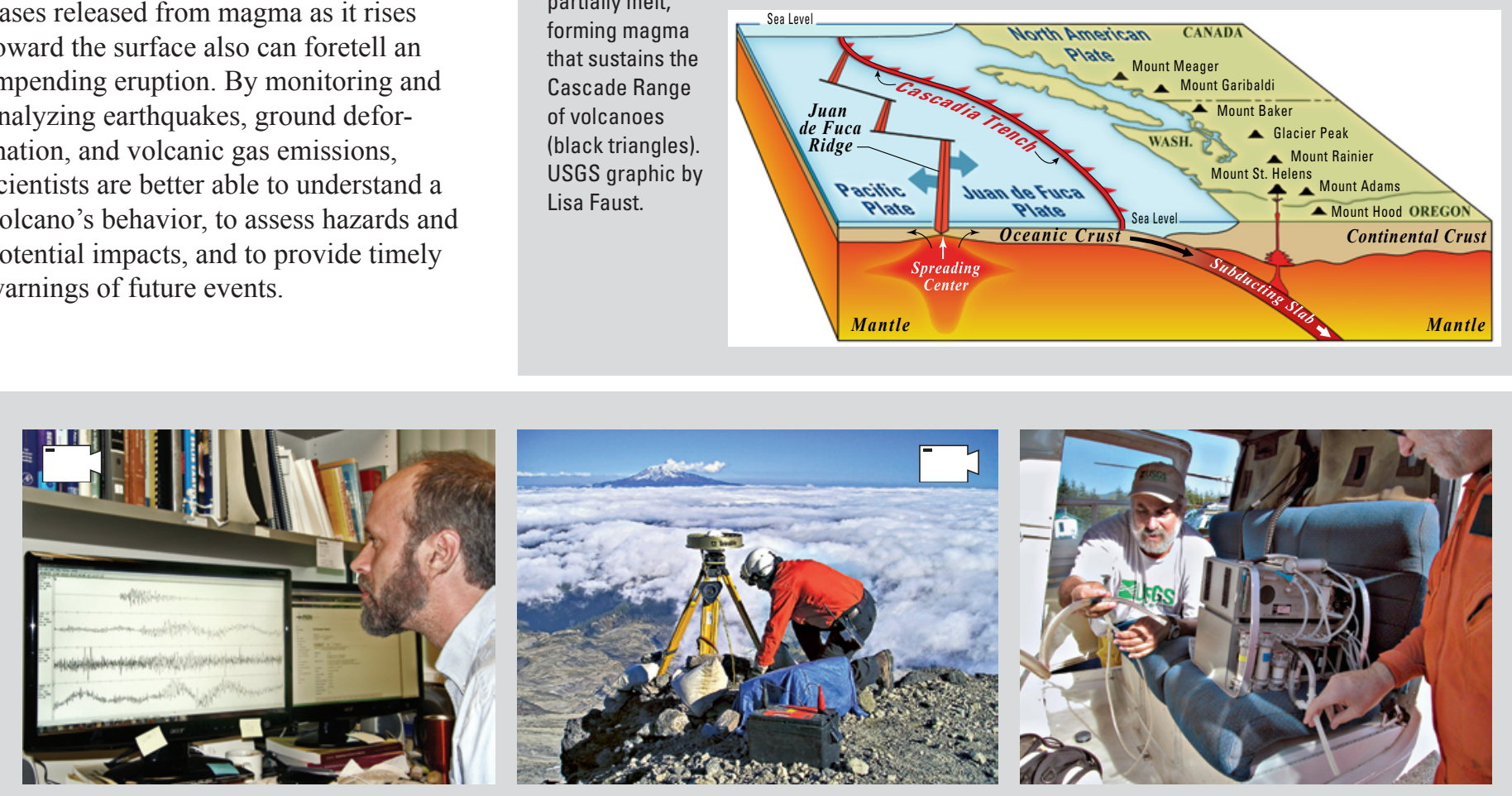

U.S. Geological Survey (USGS) scientists are monitoring Mount St. Helens in various ways in order to be able to warn of future eruptions. Left. Examining earthquake signals from Mount St. Helens at the Cascades Volcano Observatory in Vancouver, Washington. USGS photo by Carolyn Driedger, March $29,2012$. Middle: Setting up Global Positioning System (GPS) equipment to measure ground deformation on the east flank of the volcano. USGS photo by Mike Poland, September 29, 2004. Right. Installing volcanic-gas monitoring equipment in a helicopter before a flight over the volcano. Gases are released from magma as it moves upward or cools underground. USGS photo by Steve Schilling, September 27, 2004. 


\section{VOLCANO HAZARDS IN THE MOUNT ST. HELENS REGION}

This simplified hazard map shows areas that are prone to ground-based hazards from eruptions at Mount St. Helens. Mauve color indicates areas at risk from lava flows and avalanches of hot rock and gases called pyroclastic flows. Bright red areas that fade to orange and yellow indicate potential routes for lahars (volcanic mudflows). Not shown are areas subject to hazards from volcanic ash. Volcanic ashfall is often a nuisance but can be a more serious hazard during large explosive eruptions. Even in small concentrations, airborne ash can be a serious threat to aircraft (http://pubs.usgs.gov/ $f_{s} / 2010 / 3116 /$. The distribution of ash depends upon the speed and direction of winds at the time of the eruption. Sand color shows areas at risk from possible lava flows from other volcanic vents in the area.

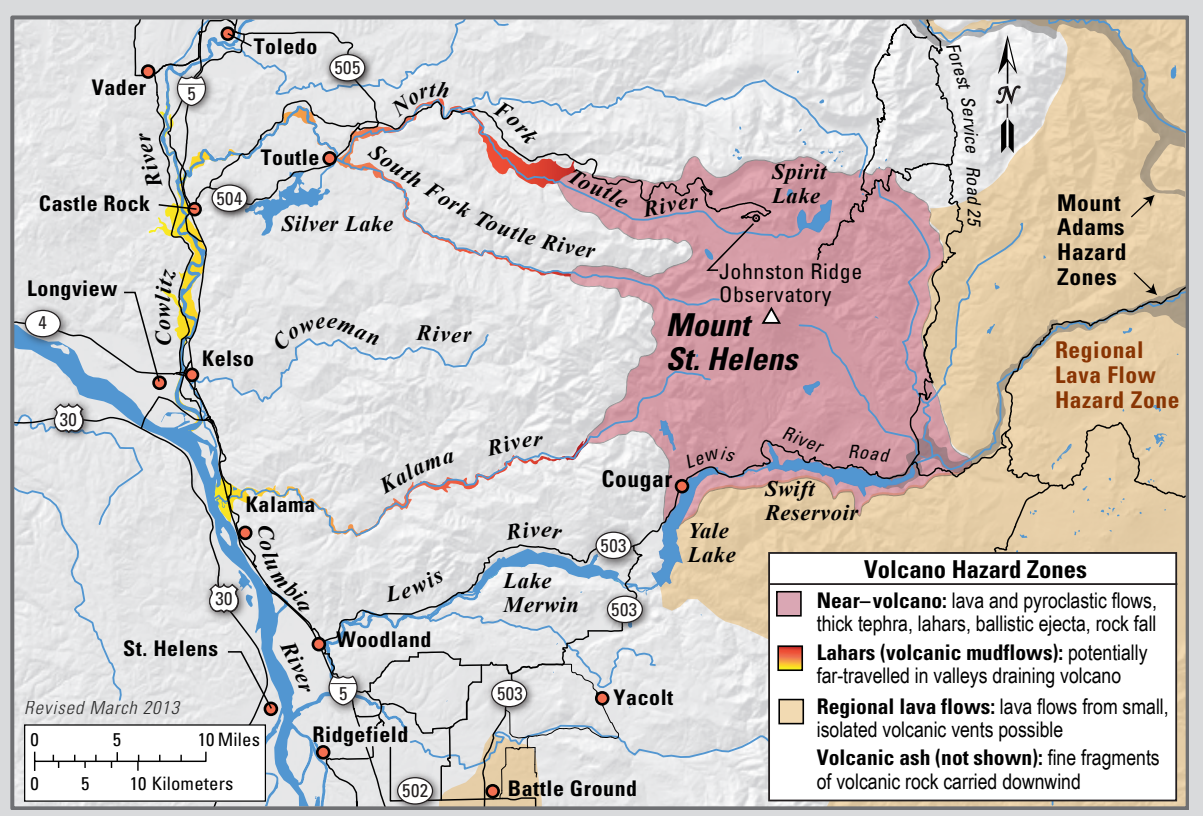

between eruptions, with occasional earthquake swarms and minor amounts of ground movement (deformation) and volcanic gas emission. Scientists continue to monitor the volcano closely for any sign of a change from the normal background level of activity, but until that happens the timing of the next eruption cannot be known. On the other hand, we know from the geologic record at Mount St. Helens that additional explosive eruptions are possible and that dome building can go on episodically for decades to centuries. So the dome-growth episodes in 1980-86 and 2004-08 are probably not the last in this series. If past trends are repeated, renewed dome growth will be preceded by a few days to weeks of heightened earthquake activity, ground deformation, and gas emission.

People who are knowledgeable and prepared can better survive a volcanic eruption. Following the recommendations
Learn: Knowledge brings power. Live safely and with less disruption by seeking out information about how your community is at risk. The USGS Cascades Volcano Observatory website (http://volcanoes.usgs.gov/ observatories/cvo/) is a good source for such information.

Inquire: Ask Federal, State, and local government agencies about community emergency plans and preparedness measures that can help protect your family.

Prepare: Stockpile supplies and develop an emergency communication plan to help your family live with greater safety and peace of mind. below will help you prepare for, and recover from, the next eruption.

The hazard zonation map for Mount St. Helens shown above reflects current understanding and will be updated as conditions warrant. Becoming familiar with the hazard map is a good start to ensuring your safety in the event of an eruption. Stay informed about the status of Mount St. Helens and other Cascade volcanoes through the news media and via the USGS Volcano Hazards Program website: http://volcanoes.usgs.gov/.

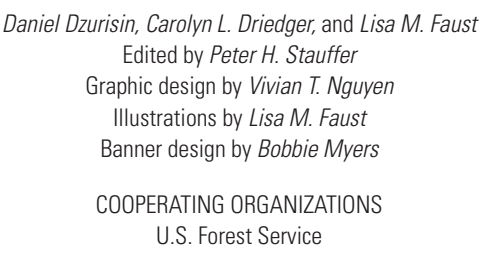
Edited by Peter H. Stauffer

Graphic design by Vivian T. Nguyen Illustrations by Lisa M. Faust Banner design by Bobbie Myers

COOPERATING ORGANIZATIONS U.S. Forest Service

For more information contact:

U.S. Geological Survey

David A. Johnston Cascades Volcano Observatory 1300 SE Cardinal Court, Bldg. 10, Suite 100

Vancouver, WA 98683-9589

Tel: (360) 993-8900, Fax: (360) 993-8980 e-mail:cvo@usgs.gov

http://volcanoes.usgs.gov

See also Pre-1980 eruptive history of Mount St. Helens, Washington (USGS Fact Sheet 2005-3045) and other USGS
Features that changed dramatically on or since May 18, 1980: Summit area slid away and
the crater formed (May 18); landslide deposit was emplaced (May 18); pyroclastic flows
formed the Pumice Plain (May 18); lava domes grew during 1980-86 and 2004-08; streams
cut deep channels and waterfalls formed; Crater Glacier grew and advanced.

Features that changed dramatically on or since May 18, 1980: Summit area slid away and
the crater formed (May 18); landslide deposit was emplaced (May 18); pyroclastic flows
formed the Pumice Plain (May 18); lava domes grew during 1980-86 and 2004-08; streams
cut deep channels and waterfalls formed; Crater Glacier grew and advanced.

Features that changed dramatically on or since May 18, 1980: Summit area slid away and
the crater formed (May 18); Iandslide deposit was emplaced (May 18); pyroclastic flows
formed the Pumice Plain (May 18); lava domes grew during 1980-86 and 2004-08; streams
cut deep channels and waterfalls formed; Crater Glacier grew and advanced.

Processes active now: Erosion by water, wind, and ice; rockfalls, mainly from crater walls; movement of Crater Glacier; magma accumulation in a reservoir a few miles beneath the volcano.

Eruption products that give the volcano its shape: Lava flows, lava domes, pyroclastic flows, lahars, ashfall deposits.

\section{volcano Fact Sheets
http://volcanoes.usgs.gov/Products/sproducts.html}

This Fact Sheet and any updates to it are available online at 